\title{
PALMAS, GRITOS, ASSOVIOS: A LEITURA DE CORDEL NA SALA DE AULA
}

\author{
Hadoock Ezequiel Araújo de Medeiros * \\ José Hélder Pinheiro Alves **
}

\begin{abstract}
Resumo: Relataremos neste artigo um recorte da vivência de leitura com o cordel Os animais têm razão ou As sete constituintes, do poeta Antonio Francisco, com alunos do primeiro ano do ensino médio da rede pública, realizada durante a pesquisa no Mestrado em Linguagem e Ensino - UFCG/PB. Como estratégia metodológica, utilizamos, no trabalho com este folheto, a leitura oral expressiva. Tomamos como base teórica Colomer (2007), Pinheiro (2007) e Marinho \& Pinheiro (2012), quanto ao ensino de literatura e da poesia; Jauss (1994) e Iser (1979), referente à Estética da recepção; Paul Zumthor (2001), sobre os aspectos da oralidade e performance ; Abreu (1999) e Galvão (2001), quanto às reflexões em torno da literatura de cordel no Nordeste. Os resultados revelam um envolvimento lúdico com a narrativa e, ao mesmo tempo, uma percepção do viés crítico social que permeia o folheto.
\end{abstract}

Palavras-chave: Cordel na sala de aula. Leitura expressiva. Formação do leitor.

\begin{abstract}
We report in this paper part of a reading experience with the cordel Os animais têm razão ou As sete constituintes, by Antonio Francisco, with first-year High School students of a public school, which is part of our research for the Master's degree in Language and Education at UFCG / PB. As a methodological strategy, we use the expressive reading. We take as a theoretical basis: Colomer (2007) Pinheiro (2007) and Marine \& Pinheiro (2012) regarding the teaching of literature and poetry; Jauss (1994) and Iser (1979), for aestheticsreception; Paul Zumthor (2001) on aspects of orality and Abreu (1999) and Galvão (2001), for the reflections around the string literature in the Northeast.
\end{abstract}

Keywords: Cordel in the classroom. Expressive reading. Readers formation.

\section{Introdução}

Quando pensamos na poesia popular na escola nos deparamos com inúmeros problemas. Em geral, os textos advindos dessa vertente, na maioria dos casos, só ganham notoriedade em datas comemorativas ou são utilizados de forma utilitária, muitas vezes, como pretexto para correções linguísticas, facilitação de conteúdos de ensino, esquecendo o seu valor estético, não favorecendo um envolvimento afetivo dos alunos com essa manifestação. Em se tratando do cordel, nos últimos anos, é notório que vem ganhando espaço nas escolas. Porém, devemos chamar atenção para o trabalho desenvolvido com os folhetos.

Alguns documentos de orientação pedagógica como as Orientações Curriculares para o Ensino Médio (2006) e os Referenciais Curriculares para o Ensino Médio da Paraíba (2006), já trazem o cordel como um texto a ser lido na sala de aula, compondo espaço juntamente com demais textos artísticos. Além de vários estudos que vêm sendo desenvolvidos na atualidade ${ }^{1}$.

\footnotetext{
* Mestre em Linguagem e Ensino, na área de concentração Literatura e Ensino, pela UFCG, tendo sua pesquisa relacionada à leitura e recepção de cordéis na sala de aula. Este artigo, portanto, é um recorte de sua pesquisa de Mestrado.E-mail: hadoockezequiel@yahoo.com.br

** Doutor em Letras-literatura Brasileira pela USP. Pós-doutorado em Literatura Brasileira pela UFMG. Professor da Universidade Federal de Campina Grande, PB, onde atua no Mestrado em Linguagem e Ensino. E-mail: helderpin@uol.com.br

${ }^{1}$ Podemos observar estudos semelhantes no banco de dissertações da página de Pós- graduação da UFCG http://www.ual.ufcg.edu.br
} 
Marinho e Pinheiro (2012), em suas reflexões, nos trazem boas sugestões, como, por exemplo, o trabalho a partir das temáticas trazidas no cordel. Na leitura de folhetos podemos criar um ambiente deleitoso de apreciação e criações, no sentido de que possa sensibilizar nossos alunos. As atividades com o folheto podem ser desenvolvidas de forma interdisciplinar, envolvendo em suas leituras uma relação com outras áreas como, as artes plásticas, a música, entre outras.

Nosso artigo apresenta um recorte de nossa experiência de pesquisa no Mestrado em Linguagem e Ensino - UFCG/PB, tendo como sujeitos colaboradores alunos da primeira série do ensino médio de uma escola estadual do município de São João do Sabugi/RN. O corpus da pesquisa contemplou folhetos de cordel do poeta Antonio Francisco ${ }^{2}$. Tomando como foco aspectos da oralidade, bastante recorrente nos textos, tivemos como objetivo observar a recepção dos estudantes aos folhetos que contemplem o viés da crítica social. Para este trabalho, selecionamos o cordel Os animais têm razão ou As sete constituintes.

Antonio Francisco atua como recitador, se apresentando em várias regiões do Brasil. Memorizando a maioria de seus cordéis, o poeta consegue envolver o público pela sua simpatia e afeto. Ele vem se destacando como um dos nomes mais importantes da Literatura de Cordel brasileira da contemporaneidade. Em seus folhetos, o poeta, ao representar os problemas sociais, as relações entre os sujeitos, a desarmonização do homem no mundo capitalista, as desigualdades de classes, entre outros aspectos, também reveste o poema de lirismo e humor, construindo imagens a partir de recursos estéticos, como a metáfora e a personificação.

Como base teórica, nos respaldamos em Colomer (2007) Pinheiro (2007) e Marinho \& Pinheiro (2012), quanto ao ensino de cordel na sala de aula; Jauss (1994) e Iser (1979), quanto à estética da recepção; Paul Zumthor (1997; 2001), sobre os aspectos da oralidade e performance na leitura de um texto. Quando trazemos reflexões em torno da literatura de cordel no Nordeste nos respaldamos em Abreu (1999) e Galvão (2001).

\section{A obra literária e o papel do leitor}

Tratando-se do contexto alemão, Jauss (1994, p. 7) destacou que nos últimos 150 anos, o estudo historiográfico da literatura trilhava um caminho de decadência ${ }^{3}$. Para ele, durante todo esse percurso, os críticos abordaram as obras dentro de um sistema cronológico e fracionário, organizando seu material "seguindo a cronologia de grandes autores e apreciando-os conforme o esquema de vida e obra". Inaugurando a Estética da Recepção, Hans Robert Jauss, diferentemente das críticas de até então, sobre a história da literatura, traz o leitor como elemento fundamental para a compreensão de uma obra literária.

Seus estudos privilegiam a recepção como sendo uma relação com a estrutura da obra, envolvendo dois pontos importantes: o momento de sua produção e de sua leitura. Com isso, destaca-se a importância do leitor como parte de um processo de comunicação literária que tem sua formulação em sete teses. Nas formulações das suas quatro primeiras teses, o autor observa que uma obra literária não depende somente das condições históricas ou

\footnotetext{
${ }^{2}$ O poeta Antonio Francisco é natural de Mossoró/RN. Ao seus 46 anos de idade deu início a sua carreira literária. É autor dos seguintes livros: Dez cordéis num cordel só (2001), Por motivos de Versos (2005), Veredas de Sombras (2007), Sete contos de Maria (2009), todos republicados na coleção completa Minha obra é um cordel, junto com a obra inédita O olho torto do rei, publicada em 2011. Além do livro Algodão e Sal em parceria com a poetisa Maria Maria.

${ }^{3} \mathrm{O}$ ensaio se refere aos anos anteriores a 1960. A tradução da obra para o português, a que temos acesso é mais recente.
} 
biográficas em que surgiu, pois para se ter uma qualidade, deve-se avaliar os "critérios da recepção, do efeito produzido pela obra e de sua fama junto à posterioridade" (JAUSS, 1994, p. 8).

Um elemento importante para a recepção é o diálogo que acontece entre historicidade da literatura e a obra literária com seus leitores, destacando o fenômeno de atualização, pois no processo de produção e de recepção, o texto sofre várias atualizações que são ornamentadas de acordo com o horizonte de expectativa de cada um. Tal horizonte se configura como sendo os conhecimentos prévios do leitor, acionados no momento de sua interação com o texto.

A obra literária não é um objeto existente por si só, pois ela oferece para cada observador, em diferentes épocas, um aspecto singular, "ela é, antes, como uma partitura voltada para a ressonância sempre renovada da leitura, libertando o texto da matéria das palavras e conferindo-lhe existência atual" (JAUSS, 1994, p. 25). Nesse sentido, a obra permanecerá viva enquanto o leitor se relacionar com ela, satisfazendo assim seu horizonte a cada época, já que o processo recepcional se realiza na atualização dos textos literários, envolvendo o leitor que os recebe, o escritor que se faz novamente produtor e, por fim, o crítico, que reflete sobre a obra.

O valor estético será definido pela distância estética envolvida por alterações, pois à medida que o horizonte de expectativa se altera, a distância estética muda. Desse modo, as grandes obras são aquelas que, de acordo com suas atualizações, nos provocam, formulando assim novas questões. Neste sentido, o processo histórico literário, de acordo com a teoria da Estética da Recepção, segue um caminho de reconstrução em que os horizontes de expectativa irão se renovando conforme o decurso de uma obra.

Vimos que, em sua teoria da recepção, Jauss destaca o leitor como sendo elemento importante para a compreensão da obra literária, pois a partir do seu horizonte de expectativa, ele pode construir sentidos para o texto. Contribuindo teoricamente com esse estudo, Iser (1979), em sua teoria sobre o efeito, formula o conceito de "vazios", que a obra apresenta em seu processo de leitura. Assim, o autor ao discutir o processo de comunicação entre texto/leitor afirma que "como atividade comandada pelo texto, a leitura une o processamento do texto ao efeito sobre o leitor" (ISER, 1979, p. 83).

Reforçando a categoria do "vazio" advinda da teoria da recepção, o autor traz como exemplo o conceito da indeterminação em que a obra de arte se diferencia e não é possuidora de autonomia, ela possui um objeto intencional. Esse objeto, portanto, é uma formação esquemática com diversos pontos de indeterminação que devem ser "vistos como condição de comunicação", a ser preenchida pelo leitor.

Pautados nessas teorias, pode-se formular caminhos metodológicos para o ensino de literatura, uma vez que esses estudos estão centrados na interação do leitor com a obra, sendo essa uma ponte de reflexão para o aluno/leitor construir sentidos para o texto. Nessa perspectiva, vemos que um dos desafios do ensino é buscar novas metodologias de leituras que possam contribuir para a formação do leitor e para que as experiências com o texto literário se tornem mais significativas. Porém, sabemos que isso não é uma tarefa fácil, visto que muitas escolas ainda não estão abertas para essa nova concepção.

\section{Vivências com a poesia na sala de aula}

A relação do homem com a poesia é algo que ocorre logo na infância, seja através de cantigas, brincadeiras de rodas, trava-línguas entre outras manifestações. Ao passar dos anos, essas vivências acabam se perdendo e as esquecemos. No entanto, muitas vezes, essa relação 
pode ser recuperada. Nesse sentido, acreditamos ser a escola um lugar onde podemos dar continuidade a essas experiências.

Alguns pesquisadores, como Pinheiro ${ }^{4}$ (2007), mostram que o trabalho com a poesia na escola ainda não é significativo quando comparado com os de outros textos literários. Para o autor, de todos os gêneros literários, a poesia é o mais "ausente". Quando ela advém do meio "popular", constatamos um problema ainda maior, uma vez que se tem uma visão de que a cultura popular não faz parte de nossa literatura nacional. Se formos analisar melhor, notamos que algumas problemáticas estão presentes desde o ensino fundamental. Professores e orientadores de leitura, normalmente não priorizam este gênero, e quando o contemplam, desconhecem metodologias adequadas. Além do mais, muitos dos profissionais não têm o hábito de leitura de poesia.

Tratando-se do contexto do ensino médio, percebemos que pouca coisa muda quando comparamos ao ensino fundamental. Dificilmente se tem um trabalho que proporcione aos alunos uma vivência significativa com a poesia. Durante a educação básica ela é marcada sublinhada pelo caráter utilitarista, tendo como objetivo, leituras que visam ilustrar um determinado tema.

Colomer (2007, p. 45. grifos da autora), destaca que "a função do ensino literário na escola pode definir-se também como a ação de ensinar o que fazer entender um corpus de obras cada vez mais amplo e complexo". Para que isso seja possível, é necessário que a aula de literatura se torne um espaço do diálogo, de forma que as percepções dos alunos/leitores possam ser compartilhadas. A poesia nas suas várias representações e composições precisa ser vivida pelos alunos.

A leitura compartilhada da poesia pode ser um dos métodos utilizados pelo professor, visto que as várias interpretações feitas pelos alunos ajudam a entender melhor o texto. Algo que até então não tinha sido percebido pode ser evidenciado na interpretação do outro. Para Colomer, compartilhar as obras com as pessoas, além de ser prazeroso, se entende "mais e melhor os livros", também faz com que o sujeito se sinta parte de uma "comunidade de leitores com referências e cumplicidades mútuas" (COLOMER, 2007, p. 143).

Se quisermos sensibilizar nossos alunos, antes de tudo, precisamos respeitar seus interesses e as suas preferências de leitura. Elas podem ser uma porta de entrada para o trabalho com a poesia e com o texto literário no geral. Contudo, como afirma Pinheiro (2007), essas condições não são realizadas da noite para o dia, é necessária uma sistematização do trabalho e esse precisa ser "constantemente avaliado".

\section{Leitura de folhetos: uma espécie de teatralidade}

Nos estudos pautados nas histórias de tradições populares e orais, observa-se que a voz se constitui como um fenômeno central, envolvida por elementos físicos e psicológicos que tendem a ultrapassar a função linguística. A esse respeito, o pesquisador Paul Zumthor (2001) traz, em seus estudos, contribuições que nos ajudam a entender o desígnio da voz poética.

Analisando algumas manifestações no período da Idade Média, Zumthor (2001) afirma que a poesia tem sido objeto de estudo, sendo necessário observar o seu efeito, quando exercido através dos aspectos da oralidade. Em suas formulações, observamos que o autor

\footnotetext{
${ }^{4}$ Devemos lembrar que as reflexões apresentadas por Pinheiro sobre a poesia na sala de aula são do ano de 2007. No entanto, quando vamos para a sala de aula, como evidenciamos em nossa experiência, vemos que essa realidade não é diferente na atualidade.
} 
foge do paradigma textual predominante na crítica do século XX. Para ele, ainda que as formas poéticas nos tenham sido transmitidas a partir da escrita,

[...] a autonomia relativa do texto, em relação à obra, diminui muito: podemos supor que, no extremo, o efeito textual desapareceria e que todo o lugar da obra se investiria dos elementos performacionais, não textuais, como a pessoa e jogo do intérprete, o auditório, as circunstâncias, o ambiente cultural e, em profundidade, as relações intersubjetivas, as relações entre as representações intersubjetivas, as relações entre a representação e o vivido (ZUMTHOR, 2001, p. 16-17).

No jogo do intérprete, a performance é, pois, um aspecto que envolve vários elementos, que vão desde a recepção, o sensorial até o "engajamento" do corpo. Alinhado a esse aspecto, realçamos uma certa experiência histórica com folhetos de cordel. Apesar de se apresentar como uma literatura escrita, contém marcas da oralidade, as quais auxiliam os poetas e o público no processo de memorização, sendo lidos "através dos olhos e da voz dos outros, tanto no ritmo da fala, quanto a melodia e canto" (AYALA, 2010, p.64). A autora define os leitores de folhetos como sendo bibliotecas "falantes e cantantes", e que a voz é um dos motivos pelo qual o público se encanta, pois o que ele queria ouvir era a "voz" do cordel.

Nesse processo, identificamos índices de uma performance que se manifestava por meio da fala e de gestos (GALVÃO, 2001). Ao mencionar o conceito de performance, Zumthor (2001, p.41) acredita ser essa uma forma de teatralidade, sendo necessária uma condição, ou seja, "a identificação pelo espectador-ouvinte, de um outro espaço, a percepção de uma alteridade espacial marcando o texto". Assim, é necessário, que haja um envolvimento tanto de quem desempenha o ato performático como de quem contempla.

Em estudo sobre a oralidade, Zumthor (2001) pôde observar que, na comunicação poética, a performance se constitui como algo vivo e "eficaz". Dessa maneira, é necessário o estudo da relação do corpo com o estudo da obra, uma vez que as pulsações dos corpos do poeta, do leitor e dos ouvintes se entrelaçam no movimento do ritmo, da melodia da linguagem e dos gestos. No cordel, notamos que o recitador se apropria dessas formas de expressão unindo voz e corpo. Na leitura em voz alta, os poetas/recitadores "confiam neles, na força dos pulmões, no poder da voz e da performance para atrair leitores/ouvintes" (MATOS, 2010, p. 18).

No desempenho performático de leitura dos folhetos, outros fatores podem ser observados, que vão além dos músculos e da respiração, um notável elemento a ser destacado - o psíquico. No envolvimento com a leitura, o corpo, enquanto matéria composta por órgãos que tendem a responder aos estímulos psíquico-emocionais reage ao texto, numa espécie de vibração, uma vez que ele "é materialização incomparável daquilo que me é próprio, realidade vivida e que determina minha relação com o mundo" (ZUMTHOR, 2001, p. 28). Ainda de acordo com o autor, os leitores da poesia oral são considerados como potenciais possuidores de uma interpretação, a qual envolve fatores físicos e psicológicos, refletindo-se, por consequência, no movimento do corpo, na hora da recepção da leitura, já que é na forma como a aceitamos que o seu efeito estético é conferido.

$\mathrm{Na}$ leitura dos folhetos, sobretudo na experiência de muitos leitores/ouvintes no interior do Nordeste, até a primeira metade do século XX, destacamos a importância do leitor que estava envolvido no fator psíquico, na criação poética do recitador que reagia à motivação que o ambiente lhe suscitava. De acordo com as pessoas que estavam presentes, a narrativa passava por uma recriação que misturava o texto escrito do folheto com a realidade do ambiente onde se estava recitando. Mesmo a narrativa poética estando memorizada, o poeta 
recorria à sua imaginação e a sua experiência para ajudarem na recriação da história oralizada, trazendo para sua leitura, fatos relacionados ao cotidiano das pessoas envolvidas.

Galvão (2001, p.167) entende que, "cada performance na poesia oral - ou, nesse caso, oralizada - ocorre entre a repetição e a criação". Corroborando essa ideia, Cavignac (2006, p. 253-254) afirma que, na recitação do cordel, o público pode produzir uma variedade de versões, o texto original estará sempre em modificação, "o recitante, primeiro interprete da história, a reformula a cada enunciação, utilizando nela seu próprio vocabulário e de acordo com as circunstâncias do momento".

Guardando em suas escrituras fortes traços da oralidade, os primeiros cordéis impressos no Nordeste datam do final do século XIX, tendo como precursores os poetas populares, Leandro Gomes de Barros e Francisco das Chagas Batista (ABREU, 1999). Datados dessa época, os folhetos começam a ganhar importância, permanecendo vivos até os dias atuais.

Entrelaçado por várias culturas, como a europeia, afro-brasileira e indígena, o folheto nordestino tornou-se uma literatura singular. Em finais dos anos oitocentistas e início do século XIX, quando os trabalhadores rurais começavam a buscar novos meios de estabilidade nas cidades, os poetas levaram em suas memórias diversas histórias e experiências vividas no campo, desenhando no papel todo esse universo cultural. O cordel ganha espaço nas ruas, cantado em tom de repentes ou declamados nos mercados públicos em dias de feira, ocupando "espaços outrora reservados aos escritores e homens de letras do país" (MARINHO e PINHEIRO, 2012, p. 18).

Vendidos a partir da leitura oral de trechos dos poemas, com intuito de persuadir o leitor, essa forma de vivência poética foi de grande importância na formação de muitos dos nordestinos da época, que sem acesso à escola aprenderam a ler e escrever a partir das experiências compartilhadas entre poetas, declamadores e ouvintes.

Em casa, as pessoas se reuniam para ouvirem declamações de folhetos, contação de histórias de trancoso ou causos. Naquele espaço, muitas vezes iniciava-se um processo de alfabetização sendo o cordel, como uma espécie de cartilha. Nesse processo, Galvão (2001, p.186) afirma que aos poucos essas leituras acabavam por se estender a "outros objetos de leituras". Dentro desse sistema de alfabetização, tinha-se, como principal elemento de motivação, a dimensão estética do cordel, a qual servia como objeto de desenvolvimento de competências de leitura.

Os participantes dessa experiência não eram apenas envolvidos pelas histórias das narrativas, mas também, pela própria beleza, que para Galvão, além da estrutura do poema, eram "narrativas com começo, meio e fim convincentes, que provoque a evocação de valores e de sentimentos e que seja capaz de transportá-los para outros espaços e tempos" (GALVÃO, 2001, p. 190). Tal beleza era apreciada em um processo de leitura "partilhada", em que as habilidades e competências orais desempenharam um papel fundamental no que diz respeito à construção de sentidos da leitura.

\section{5 "Palmas, gritos e assovios"}

Em nossa Experiência, utilizamos estratégias metodológicas de leituras baseadas na estética da recepção (tendo o leitor como sujeito da leitura), favorecendo uma leitura compartilhada, de forma que os alunos/leitores puderam construir sentidos para o poema. Dentre as estratégias, destacamos a leitura oral e expressiva. 
Nossa experiência se organizou a partir de algumas instâncias, como contato com o ambiente escolar, conversa com o professor e gestor da escola, coleta de dados, levantamento sobre o conhecimento de leitura de poesia dos alunos, observação de algumas aulas e elaboração de sequências didáticas, transcrição e definição de categorias de análise dos dados obtidos, análise e interpretação dos dados e reflexão crítica acerca do fenômeno observado e da metodologia utilizada ${ }^{5}$.

$\mathrm{Na}$ análise da experiência de leitura com os cordéis de Antonio Francisco delineamos os dados coletados a partir de duas categorias específicas, oralidade e percepção da crítica social. Nesse artigo iremos nos deter apenas aos aspectos da oralidade observados durante a recepção de um folheto. Para o desenvolvimento do trabalho com a leitura, organizamos uma antologia com folhetos do poeta Antonio Francisco. A saber: Um Bairro chamado Lagoa do Mato, Os animais têm razão ou As sete constituintes, Balance a rede do Mundo, A Casa que A Fome Mora e $O$ poema que não fiz. Iremos, portanto, nos deter apenas a análise da recepção do folheto Os animais têm razão.

No tocante as temáticas trazidas nos folhetos, merecem destaque as que retomam o mundo animal, principalmente histórias que se caracterizam pelo tempo mítico em que os bichos falavam. Embora as narrativas com personagens que são representados por animais tenham uma perspectiva de leitura voltada para crianças, elas também despertam o interesse de leitores adolescentes e adultos. Como sabemos, no caso do folheto nordestino, as histórias não têm público específico. Muitos nordestinos se criaram ouvindo e recitando cordéis com a temática dos bichos. Marinho e Pinheiro (2012) citam alguns desses folhetos que encantaram o público ouvinte, a saber: No tempo em que os bichos falavam, de José Francisco Borges, outro com o mesmo título, de Manuel Pereira Sobrinho, $O$ casamento do calango com a lagartixa, do mesmo autor e A greve dos bichos, de Zé Vicente, dentre outros.

$\mathrm{Na}$ atualidade, podemos encontrar diversos folhetos com essas histórias, dentre eles Os sete constituintes ou os Animais têm razão, de Antonio Francisco - trata-se de um testemunho em que os bichos apresentam seus pontos de vista com relação às atitudes dos seres humanos, como pode ser evidenciado na fala da cobra: É certo eu tenho veneno/ Mas nunca fiz um canhão/E entre mim e o homem, existe uma contradição/ $\mathrm{O}$ meu veneno é na presa/ O dele é no coração. Esse folheto possui um final com tom de ensinamento, como nas fábulas, no entanto, apresenta também o caráter lúdico.

Assim como nos folhetos mais conhecidos que tratam da fabulação, o cordel de Antonio Francisco também apresenta os animais em ação. $\mathrm{O}$ folheto possui 35 estrofes, sendo 34 em sextilhas e a última em septilha. Nas três primeiras estrofes o poeta traz um cenário que mostra a paisagem do sertão. Apesar do clima seco e quente, ele encontra a beleza e a resistência no juazeiro, árvore que sempre está verde, mesmo no tempo da escassez de água.

A história ambienta-se em torno dessa árvore, onde o narrador encontra-se na copa do juazeiro e os personagens, animais, ficam embaixo, discutindo as atitudes do homem "num clima espetacular". Após fazer uma viagem, passando por várias cidades, o narrador personagem resolve se arranchar no juazeiro. Depois de dormir algumas horas, ele acorda com o som de gritos. Ele olha para baixo para observar o que está acontecendo e vê um porco falando. A partir de então, inicia um debate entre os animais.

Os personagens animados são: O porco, o rato, a vaca, a cobra, o morcego, o burro e o cachorro. Diferente de alguns cordéis com essa temática que trazem para as histórias animais, em sua maioria, da caatinga, no cordel de Antonio Francisco, os animais fazem parte de espaços urbanos, principalmente bichos que são domesticados, que convivem com o

\footnotetext{
${ }^{5}$ Para um melhor conhecimento da experiência como um todo, consulte-se: http://www.ual.ufcg.edu.br/posle/images/3/34/Haddock_De_cal\%C3\%A7a_curta_e_chinela_a_poesia_de_Ant onio_Francisco_na_sala_de_aula.pdf
} 
homem. Com um caráter de fábula, os folhetos em que predominam a temática dos bichos, geralmente atribuem profissões e costumes aos animais (PINHEIRO, 2008b).

No folheto, o poeta embora não traga essas profissões, cada animal possui uma caracterização típica, como por exemplo, o "burro que dá coice, e sabe morder". Porém, essas características não são usadas, pois ao contrário dos homens, os animais do folheto não utilizam suas habilidades para ferir como evidenciamos na fala do burro: "Eu sei que sou melhor do que ele/Mas se eu morder o homem/Ou se eu der um coice nele/É mesmo que está trocando/O meu juízo no dele".

As histórias fabulares trazem os bichos vivendo situações como festas, reuniões, danças, intrigas, as quais são permeadas pelo humor. A exemplo disso, no folheto de Antonio Francisco em questão, tendo como pano de fundo a crítica social, o poeta a reveste de humor, tornando a leitura mais lúdica. Como é evidenciado na fala do cachorro: "Eu nunca vou entender/ Porque o homem é assim:/ Se odeiam, fazem guerra/ E tudo quanto é ruim/ E a vacina da raiva/Em vez deles, dão em mim".

No folheto os animais têm aspectos da vivência do sertanejo. $\mathrm{O}$ eu poético demonstra um conhecimento peculiar com relação à natureza e ao comportamento dos animais, fazendo o leitor se encantar, ora com imagens como "A cobra se levantou/Ficou na ponta do rabo", ora com o embalo da sonoridade como as aliterações e assonâncias, "Mas de repente um esturro/É que o rato pulando/pisou no rabo do burro/E o burro partiu pra cima/Do rato pra dar-lhe um muro".

Para realizarmos a leitura do folheto em sala de aula, adotamos algumas estratégias com a leitura oral. Ao iniciarmos, propusemos à turma, uma leitura silenciosa. Porém, acatamos a proposta dos alunos que preferiram uma tarefa em conjunto. De forma expressiva, foram lidas, pelo pesquisado, as quatro primeiras estrofes que descrevem o cenário da história e em seguida os alunos deram continuidade, com a sugestão de que um dos alunos fizesse a fala do narrador e os outros a fala de cada personagem.

De início, pensávamos que encontraríamos alguma rejeição, mas fomos surpreendidos pela atitude dos alunos que tomaram a iniciativa de ler. O Aluno $1^{6}$ prosseguiu a partir da quinta estrofe, quando se inicia a experiência do personagem narrador, vivida na copa do juazeiro: "E foi de cima de um deles/Num clima espetacular/Que eu ouvi um testemunho/Que vocês vão delirar [...]". O Aluno 2 prosseguiu com a leitura até a estrofe nove, quando o narrador encerra sua fala para entrar a voz dos animais: "Quando eu olhei para baixo/Eu vi um porco falando/Um cachorro e uma cobra [...]". E assim, demos continuidade à leitura.

Terminada a fala do narrador, o Aluno 2 interpretou a fala do porco: - "pelas barbas do capeta!/ Se nós ficarmos parados/ A coisa vai ficar preta [...] Sem que apresentássemos sugestões, os próprios alunos tomaram uma iniciativa da leitura oral expressiva. Ao ler a estrofe em que se pronuncia o porco, o Aluno, em tom de voz alta e gesticulando com os braços, fez uma interpretação que conseguiu chamar a atenção dos colegas para o texto.

Os outros alunos foram se envolvendo na leitura e, a cada fala dos personagens/animais que ia surgindo no folheto, eles davam um tom e gestos que os representassem. No tocante à fala da vaca, surgiu um fato interessante. Nenhum dos alunos queria interpretá-la e falavam: "Quem será a vaca?”. Notamos que eles estavam brincando com a situação, pois associaram esse animal a uma imagem preconceituosa, relacionando ela às mulheres gordas.

Diante disso, conversamos com eles a respeito desse preconceito e apontamos outras interpretações simbólicas da vaca, que de acordo com (CHAVALIER; GHEERBRANT, 2007) ela pode ter uma representação materna. Com isso, eles acabaram aceitando a

\footnotetext{
${ }^{6}$ Como forma de preservar a identidade dos alunos, iremos representá-los por números.
} 
interpretação e deram continuidade à leitura. Na realização feita para representar a fala da vaca: [...] Eu convivo com o homem,/ Mas sei que ele não presta./ [...] É um mal-agradecido,/ Orgulhoso, inconsciente./ É doido e se faz de cego,/ Não sente o que a gente sente,/ E quando nasce é tomando/ A pulso o leite da gente. A voz foi realizada em um tom grave, assim como a que foi feita para o porco e o burro. Já para a representação do rato: “[...] Prestem atenção/Eu também já não suporto/Ser chamado de ladrão", a Aluna 3, ao contrário do Aluno 2, fez uso de uma voz aguda e estridente.

A partir dessas performances feitas pelos alunos, fomos observando que o tom das vozes está associado à imagem do animal; se fosse um animal de grande porte, a voz era grave, se fosse pequeno, aguda. Notamos também que, nas interpretações para os bichos, os alunos acionavam o seu conhecimento de mundo, uma vez que para cada animal, existia uma representação simbólica, como evidenciamos, por exemplo, com a vaca. Para os alunos, a imagem da vaca seria uma ofensa e, já que eles estavam incorporando a fala dos personagens, ninguém queria ser esse animal.

Reforçamos essa ideia da relação com o conhecimento de mundo dos alunos, quando observamos a leitura expressiva deles para a estrofe em que aparece a cobra: [...] A cobra se levantou, Ficou na ponta do rabo E disse: - "Também eu sou/Perseguida pelo homem/Pra todo canto que eu vou". Nessa passagem, o Aluno 1 levantou-se da cadeira e imitou os gestos da cobra. Prosseguindo a leitura performática, fez uma tonalidade de voz que se aproximava dos personagens malvados, uma voz com tom arrogante. Já para o cachorro foi diferente. O Aluno 4, que realizou a leitura, imitou os latidos do animal nos seguintes trechos: Todos vocês têm razão.../ O homem é um quase nada/ Rodando na contramão,/ Um quebra cabeça humano/ Sem prumo sem direção.

Esse momento foi divertido, a turma ria e o aplaudia. Como eles estavam criando a fala dos personagens de acordo com o conhecimento que tinham sobre cada animal, para o morcego, não teve muita expressividade. Acreditamos que isso se deu pelo fato deles não terem a ideia formada do som emitido por esse animal, por isso a expressividade dada por eles não tenha sido da mesma forma que foi para os outros bichos.

No decorrer das falas de cada animal do folheto, encontramos passagens em que todos os bichos se manifestam e elogiam a fala de um deles através de gritos, palmas e assovios. No trecho "Os bichos bateram palmas", todos os alunos, seguindo a leitura, bateram palmas. O porco deu com a mão [...], o Aluno 2, acompanhando o movimento da imagem, levantou sua mão. Palmas, gritos e assovios/Ecoaram na floresta [...]/Entre aplausos e gritos", toda a turma aplaudiu, gritaram e assoviaram. Dessa forma, acreditamos que a leitura oral do cordel lido foi significativa para interação dos alunos com o texto, uma vez que eles acabaram se identificando com os personagens do folheto e criando meios, alterações na tonalidade da voz e gestos para se expressarem.

\section{Considerações finais}

A experiência com a poesia popular - o cordel - mostrou-nos que é possível na aula de literatura, seguir caminhos diferentes dos que comumente são propostos em sala de aula, ou seja, escolha de textos e autores que correspondem ao que convencionalmente chamamos de eruditos. Os textos da esfera popular, comumente não vistos como parte da literatura nacional, podem ter uma aproximação com os horizontes de expectativas dos alunos e promover a fruição estética. 
Ao nos preocuparmos com o ensino de literatura, pomos em evidência, nessa experiência, a leitura de textos populares na escola. No caso do cordel, vimos que essa manifestação, que se mantém atualizada pode e deve ser lida em sala de aula. O cordel pode ser explorado pela percepção temática e formal (linguagem, imagens), o que oportuniza ao professor se utilizar de várias estratégias de leituras, desde a oral até a dramática.

A chave para o envolvimento dos alunos com os folhetos lidos esteve principalmente no processo metodológico escolhido. Uma metodologia que foi embasada na valorização do leitor, inspirados na Estética da Recepção, sobretudo no conceito de partitura formulado por Jauss (1994), destacando o leitor como elemento fundamental na construção de sentidos do texto. Nossa atitude diante do ensino de literatura foi de possibilitar a experiência estética dos alunos, no sentido de que estes pudessem despertar o interesse pela leitura do folheto.

A interação dos alunos com a leitura se deu por vários motivos. O primeiro, pela ludicidade que o próprio cordel proporciona; segundo, pela maneira como os cordéis foram apresentados, ou seja, levantamento do horizonte de expectativas, fundamentados na teoria de Jauss (1994); leitura expressiva/ compartilhada Colomer (2007) e debates. Graças a essas estratégias, foi possível envolver os alunos na leitura, contribuindo para que eles preenchessem os vazios deixados no texto.

Por fim, a vivência com o cordel por alunos do ensino médio revelou a importância dessa literatura na escola. Apoiados no conceito de leitura compartilhada referida por Colomer (2007), a vivência com o folheto de Antonio Francisco proporcionou a troca de experiências entre aluno/aluno e professor pesquisador/ aluno, possibilitando uma prática de leitura que não se prendeu aos limites do livro didático. Nosso principal objetivo foi despertar o interesse por textos literários dos jovens leitores a partir da vivência com os cordéis, proporcionando-lhes uma sensibilização e um olhar crítico com relação à poesia.

Este trabalho pretendeu, a partir da nossa experiência de leitura com o cordel, trazer algumas reflexões em torno do ensino de literatura, especialmente a poesia de origem popular, mostrando estratégias metodologias que podem ser utilizadas. Também foi possível mostrar que a poesia popular pode ser levada para a sala de aula, sendo trabalhada de forma que sensibilize nossos alunos. Contudo, como lembra Marinho e Pinheiro (2012), devemos ter uma relação afetiva com essa forma de arte para que o trabalho com o cordel na escola se torne significativo.

\section{Referências}

ABREU, M. Histórias de cordéis e folhetos. Campinas, SP: Mercado de Letras: Associação de Leitura do Brasil, 1999. (Col. Histórias de Leitura).

CAVIGNAC, J. A literatura de Cordel no Nordeste do Brasil: da história escrita ao relato oral. Trad. Nelson Patriota. Natal/RN: EDUFRN, 2006.

COLOMER, T. Andar entre livros: a leitura literária na escola. Trad. Laura Sandroni. São Paulo: Global, 2007.

BRASIL, Linguagens, códigos e suas tecnologias: conhecimento de literatura. In: Orientações curriculares para o ensino médio. Brasil: MEC / Secretaria de Educação Básica, 2006, p. 49-81. 
GALVÃO, A. M. O. Cordel: leitores e ouvintes. Belo Horizonte: Autêntica, 2001. (Coleção Historial, 9).

ISER, W. A interação do texto com o leitor. In: LIMA, Luiz Costa (sel., trad. Introd.). A literatura e o leitor. Rio de Janeiro: Paz e Terra, 1979, p. 83-132.

JAUSS, H. R. A história da literatura como provocação à teoria literária. Trad. Sérgio Tellori. São Paulo: Ática, 1994.

MARINHO, A. C.; PINHEIRO, H. Cordel no cotidiano escolar. São Paulo: Cortez, 2012. (coleção trabalhando com... na escola)

MATOS, E. Literatura de cordel: Poética, corpo e voz. In: MENDES, Simone (Org.). Cordel nas Gerais: oralidade, mídia e produção de sentidos. Fortaleza: Expressão Gráfica Editora. 2010. p. 15-27.

MELO, A. F. T. Minha obra é um cordel. 10ª ed. Fortaleza: IMEPH, 2011. (Obra Completa)

PARAÍBA. Referenciais Curriculares para o ensino médio da Paraíba: Linguagens, códigos e suas tecnologias: conhecimento de Literatura. João Pessoa: [s.n], 2006. p. 81-97.

PINHEIRO, H. Poesia na sala de aula. 3 ed. rev. ampl. Campina Grande: Bagagem, 2007.

ZUMTHOR, P. Letra e a Voz. Trad. Amalio Pinheiro e Jerusa Pires Fereira. São Paulo: Companhia das Letras, 2001.

Recebido em: setembro 2014. Aprovado em: dezembro 2014. 
Anexo:

OS ANIMAIS TÊM

RAZÃO OU AS SETE

\section{CONSTITUINTES}

- Antonio Francisco

Quem já passou no sertão

E viu o solo rachado,

A caatinga cor de cinza,

Duvido não ter parado

Pra ficar olhando o verde

Do juazeiro copado.

E sair dali pensando:

Como pode a natureza

Num clima tão quente e seco,

Numa terra indefesa

Com tanta adversidade

Criar tamanha beleza.

O juazeiro, seu moço,

É pra nós a resistência,

A força, a garra e a saga,

$\mathrm{O}$ grito de independência

Do sertanejo que luta

$\mathrm{Na}$ frente da emergência.

Nos seus galhos se agasalham

Do periquito ao cancão.

É hotel do retirante

Que anda de pé no chão,

$O$ general da caatinga

E o vigia do sertão.

E foi debaixo de um deles

Que eu vi um porco falando,

Um cachorro e uma cobra

E um burro reclamando,

Um rato e um morcego

E uma vaca escutando.

Isso já faz tanto tempo Que eu nem me lembro mais

Se foi pra lá de Fortim,

Se foi pra cá de Cristais,

Eu só me lembro direito

Do que disse os animais.

Eu vinha de Canindé

Com sono e muito cansado,

Quando vi perto da estrada

Um juazeiro copado.

Subi, armei minha rede

E fiquei ali deitado.

Como a noite estava linda,

Procurei ver o cruzeiro,

Mas, cansado como estava,

Peguei no sono ligeiro.

Só acordei com uns gritos

Debaixo do juazeiro.
Quando eu olhei para baixo

Eu vi um porco falando,

Um cachorro e uma cobra

E um burro reclamando,

Um rato e um morcego

E uma vaca escutando.

O porco dizia assim:

- "Pelas barbas do capeta!

Se nós ficarmos parados

A coisa vai ficar preta...

Do jeito que o homem vai,

Vai acabar o planeta.

Já sujaram os sete mares

Do Atlântico ao mar Egeu,

As florestas estão capengas,

Os rios da cor de breu

E ainda por cima dizem

Que o seboso sou eu.

Os bichos bateram palmas,

O porco deu com a mão,

$\mathrm{O}$ rato se levantou $\mathrm{E}$ disse:

- "Prestem atenção,

Eu também já não suporto

Ser chamado de ladrão.

O homem sim, mente e rouba,

Vende a honra, compra o nome.

Nós só pegamos a sobra

Daquilo que ele come

E somente o necessário

Pra saciar nossa fome."

Palmas, gritos e assovios

Ecoaram na floresta,

A vaca se levantou

E disse franzindo a testa:

- "Eu convivo com o homem,

Mas sei que ele não presta".

É um mal-agradecido,

Orgulhoso, inconsciente.

É doido e se faz de cego,

Não sente o que a gente sente,

E quando nasce e tomando

A pulso o leite da gente.

Entre aplausos e gritos,

A cobra se levantou,

Ficou na ponta do rabo

E disse: - "Também eu sou

Perseguida pelo homem

Pra todo canto que vou.

Pra vocês o homem é ruim,

Mas pra nós ele é cruel.

Mata a cobra, tira o couro,

Come a carne, estoura o fel,

Descarrega todo o ódio

Em cima da cascavel.
É certo, eu tenho veneno, Mas nunca fiz um canhão. E entre mim e o homem,

Há uma contradição

O meu veneno é na presa,

$\mathrm{O}$ dele no coração.

Entre os venenos do homem,

O meu se perde na sobra...

Numa guerra o homem mata

Centenas numa manobra,

Inda tem cego que diz:

Eu tenho medo de cobra."

A cobra inda quis falar,

Mas, de repente, um esturro.

É que o rato, pulando,

Pisou no rabo do burro

E o burro partiu pra cima

Do rato pra dar-lhe um murro.

Mas, o morcego notando

Que ia acabar a paz,

Pulou na frente do burro

E disse: - "Calma, rapaz!...

Baixe a guarda, abra o casco,

Não faça o que o homem faz."

O burro pediu desculpas

E disse: - "Muito obrigado,

Me perdoe se fui grosseiro,

É que eu ando estressado

De tanto apanhar do homem

Sem nunca ter revidado."

O rato disse: - "Seu burro,

Você sofre porque quer.

Tem força por quatro homens,

Da carroça é o chofer...

Sabe dar coice e morder,

Só apanha se quiser."

O burro disse: - "Eu sei

Que sou melhor do que ele.

Mas se eu morder o homem

Ou se eu der um coice nele

É mesmo que estar trocando

O meu juízo no dele.

Os bichos todos gritaram:

_"Burro, burro...muito bem!"

O burro disse: - "Obrigado,

Mas aqui ainda tem

O cachorro e o morcego

Que querem falar também."

O cachorro disse: - "Amigos,

Todos vocês têm razão...

O homem é um quase nada

Rodando na contramão,

Um quebra-cabeça humano

Sem prumo e sem direção.
Eu nunca vou entender

Por que o homem é assim:

Se odeiam, fazem guerra

E tudo o quanto é ruim

$\mathrm{E}$ a vacina da raiva

Em vez deles, dão em mim.”

Os bichos bateram palmas

E gritaram: - "Vá em frente."

Mas o cachorro parou, Disse:

- "Obrigado, gente,

Mas falta ainda o morcego

Dizer o que ele sente."

O morcego abriu as asas,

Deu uma grande risada

E disse: - "Eu sou o único

Que não posso dizer nada

Porque o homem pra nós

Tem sido até camarada.

Constrói castelos enormes

Com torre, sino e altar,

Põe cerâmica e azulejos

E dão pra gente mora

E deixam milhares deles

Nas ruas, sem ter um lar."

O morcego bateu asas,

Se perdeu na escuridão,

$\mathrm{O}$ rato pediu a vez,

Mas não ouvi nada, não.

Peguei no sono e perdi

$\mathrm{O}$ fim da reunião.

Quando o dia amanheceu,

Eu desci do meu poleiro.

Procurei os animais,

Não vi mais nem o roteiro,

Vi somente umas pegadas

Debaixo do juazeiro.

Eu disse olhando as pegadas:

Se essa reunião

Tivesse sido por nós,

Estava coberto o chão

De piúbas de cigarros,

Guardanapo e papelão.

Botei a maca nas costas

E saí cortando o vento.

Tirei a viagem toda

Sem tirar do pensamento

Os sete bichos zombando

Do nosso comportamento.

Hoje, quando vejo na rua

Um rato morto no chão,

Um burro mulo piado,

Um homem com um facão

Agredindo a natureza,

Eu tenho plena certeza:

Os bichos tinham razão. 